\title{
Severe trauma in young permanent tooth: a case report
}

\author{
Trauma severo em dente permanente jovem: relato de caso
}

\author{
Ana Luiza Costa Silva de OMENA ${ }^{1}$ (iD 0000-0002-4006-4004 \\ Ivana Aguiar FERREIRA ${ }^{1}$ iD 0000-0003-3548-2276 \\ Claudia Lima RAMAGEM ${ }^{1}$ iD 0000-0002-5956-6215 \\ Kelly Maria Silva MOREIRA ${ }^{1}$ iD 0000-0002-1137-3908 \\ Isabela FLORIANO² iD 0000-0002-7352-5655 \\ José Carlos IMPARATO3 ${ }^{3}$ iD 0000-0002-1990-2851
}

\begin{abstract}
Dentoalveolar trauma is a severe traumatic injury involving alveolar bone and dental structures. Like any trauma, it can leave irreparable sequelae and even cause tooth loss. The aim of this study is to report on the case of a dentoalveolar trauma in a 10-year-old male patient and the treatment performed with 12-month follow-up. The child had lateral luxation and displacement of teeth 11 and 21 in labial direction after a fall from his own height. The patient was examined at a hospital, received medication and was referred to a dental clinic. At the dental office, the teeth were repositioned, as well as received endodontic treatment and dental reanatomization. Two months after the trauma, root resorption was observed externally, which remained stable for 12 months. It was concluded that post-trauma treatment should be immediate and that follow-up sessions should be done carefully to minimize sequelae and to receive better prognosis.
\end{abstract}

Indexing terms: Dentition, permanent. Pediatric dentistry; Tooth injuries.

\section{RESUMO}

Traumatismo dentoalveolar é uma lesão traumática grave envolvendo osso alveolar e estruturas dentárias. Como qualquer trauma, pode deixar sequelas irreparáveis e até causar perda dentária. O objetivo deste estudo é relatar o caso de um trauma dentoalveolar em um paciente de 10 anos e o tratamento realizado com 12 meses de acompanhamento. A criança apresentou luxação lateral e deslocamento dos dentes 11 e 21 na direção labial após uma queda da própria altura. O paciente foi examinado em um hospital, recebeu medicação e foi encaminhado a uma clínica odontológica. No consultório odontológico, os dentes foram reposicionados, posteriormente, tratados endodônticamente e realizado a reanatomização dentária. Dois meses após o trauma, a reabsorção radicular foi observada externamente, permanecendo estável por 12 meses. Concluiu-se que o tratamento pós-trauma deve ser imediato e que as sessões de acompanhamento devem ser realizadas com cuidado, a fim de minimizar sequelas e obter melhor prognóstico.

Termos de indexação: Dentição permanente. Odontopediatria. Traumatismos dentários.

$\boldsymbol{v} \boldsymbol{\nabla} \boldsymbol{v}$

1 Faculdade São Leopoldo Mandic. Rua José Rocha Junqueira, 13, 13045-755, Campinas, SP. Brasil. Correspondence to: JC IMPARATO. E-mail: <jimparato@usp.br>.

${ }^{2}$ Centro Universitário Uninovafapi, Departamento de Odontologia. Teresina, Piauí, Brasil.

3 Universidade de São Paulo, Departamento de Odontologia. São Paulo, São Paulo, Brasil.

$\boldsymbol{\nabla} \mathbf{v}$

How to cite this article

Omena ALCS, Ferreira IA, Ramagem CL, Moreira KMS, Floriano I, Imparato JC. Severe trauma in young permanent tooth: a case report. RGO, Rev Gaúch Odontol. 2020;68:e20200007. http://dx.doi.org/10.1590/1981-86372020000073667 


\section{INTRODUCTION}

Dentoalveolar trauma is a severe traumatic injury involving the alveolar process and dental structures [1-2]. Like any trauma, it can leave irreparable sequelae and even cause tooth loss [3]. Dental treatment of a patient with dentoalveolar trauma should begin with the exclusion of possible head trauma, immunization verification and search for details of the accident [2].

There is a guideline for each dental injury, and the follow-up procedures vary according to the time required for healing injured structures [1]. Prevalence studies indicate that male schoolchildren are affected more and that cases of dental trauma are more frequent during school holidays $[3,4]$. The anterior teeth, mainly the central incisors, are the most involved [5].

Proper diagnosis, treatment planning and followup are important to ensure a favourable outcome. When the treatment is performed quicker, the prognosis is better because the chance of resorptions and other sequels post-trauma is lower. The aim of this study is to report a clinical case of severe dental trauma in a 10-year-old male patient with 1-year follow-up whose care was immediate.

\section{CASE REPORT}

A 10-year-old male patient had dentoalveolar trauma after a fall from his own height in a water park. He went to the dental office 2 hours after the trauma, as referred by the hospital, where he received medication (analgesic). The child had lateral luxation and displacement of teeth 11 and 21 in labial direction, as well as enameldentin-pulp fracture in both teeth. There was not a fracture in the alveolar bone.

The anamnesis revealed that the patient did not feel pain, had no systemic impairment and had the immunization updated. With his collaboration, the region was cleaned with $2 \%$ chlorhexidine, bone and dental fragments were removed and suture of the soft tissues with silk thread was performed. The teeth were then repositioned into their original location and stabilized using a semi-rigid splint with orthodontic wire. Both the parents and the patient were advised regarding meticulous oral hygiene, rinsing with alcohol free chlorhexidine gluconate $0.2 \%$ for 2 weeks and administration of systemic antibiotic.
In the next day, a panoramic radiograph was performed that revealed adequate dental repositioning. Two weeks later, good tissue healing was observed, and the suture was removed. The splint was removed after 4 weeks. Eight weeks after trauma, endodontic treatment of teeth 11 and 21 was performed with calcium hydroxide. It is possible to observe radiographically external radicular resorption in both teeth, possibly caused by large tooth dislocation because of trauma and delayed endodontic treatment.

The reanatomization was performed after 6 months of trauma with a fiberglass pin and composite resin. The final restoration satisfactorily restored the aesthetic and dental function.

After 1-year follow-up, a periapical radiography was taken, and stability of the external root resorption was verified. The restoration was clinically adequate.

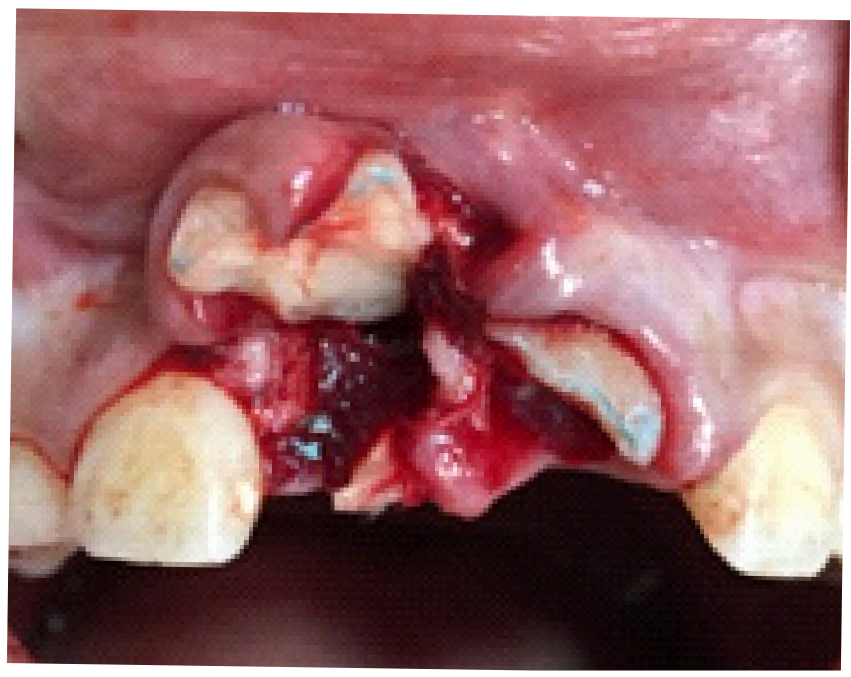

Figure 1. Clinical aspect of the anterior region immediately after the trauma.

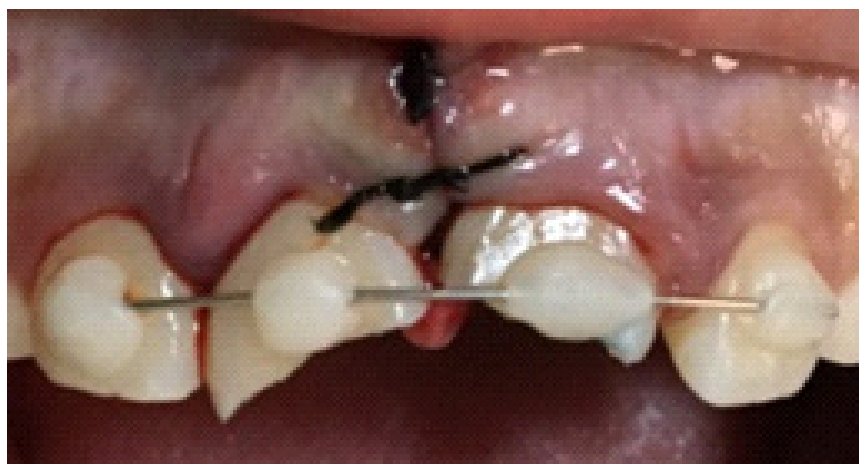

Figure 2. Clinical aspect of the anterior region after suture and semi-rigid splint. 


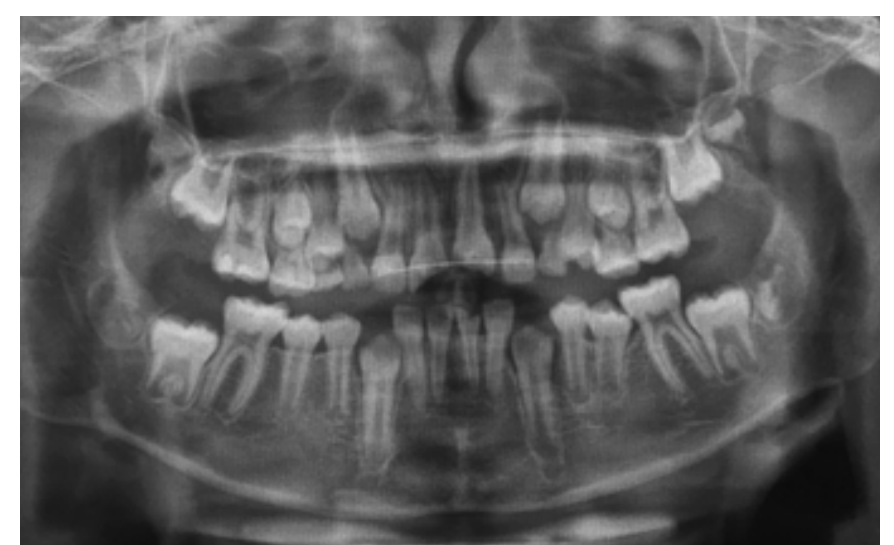

Figure 3. Panoramic radiography one day after treatment.

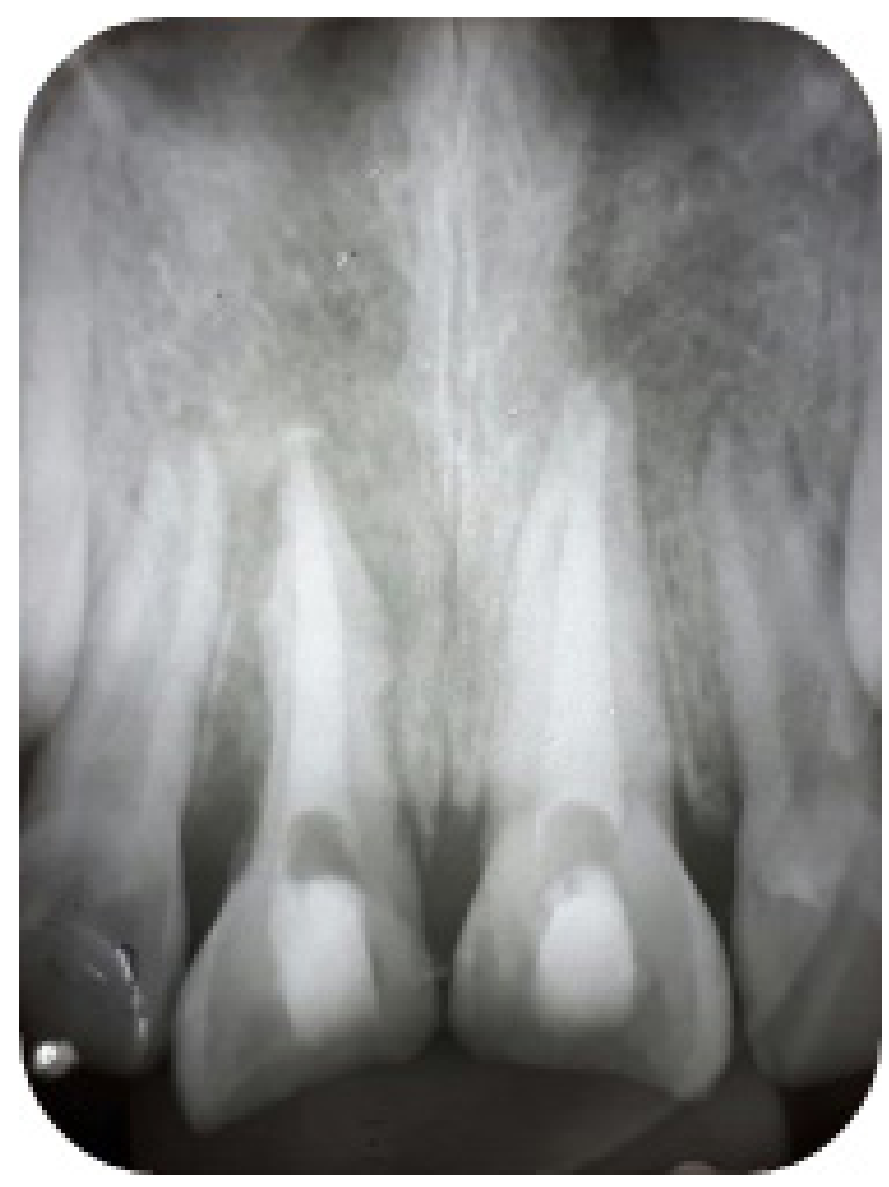

Figure 4. Radiographic aspect of endodontic treatment performed 8 weeks after trauma.

\section{DISCUSSION}

The main causes of dentoalveolar trauma are violence, traffic accidents and sports practice [6]. Traumatic dental injuries comprise $5 \%$ of all injuries and are in the

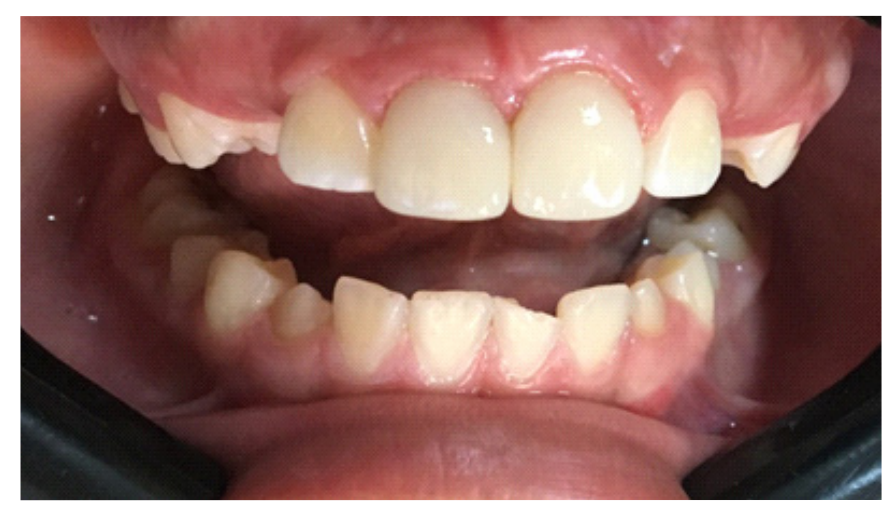

Figure 5. Final result after aesthetic restoration.

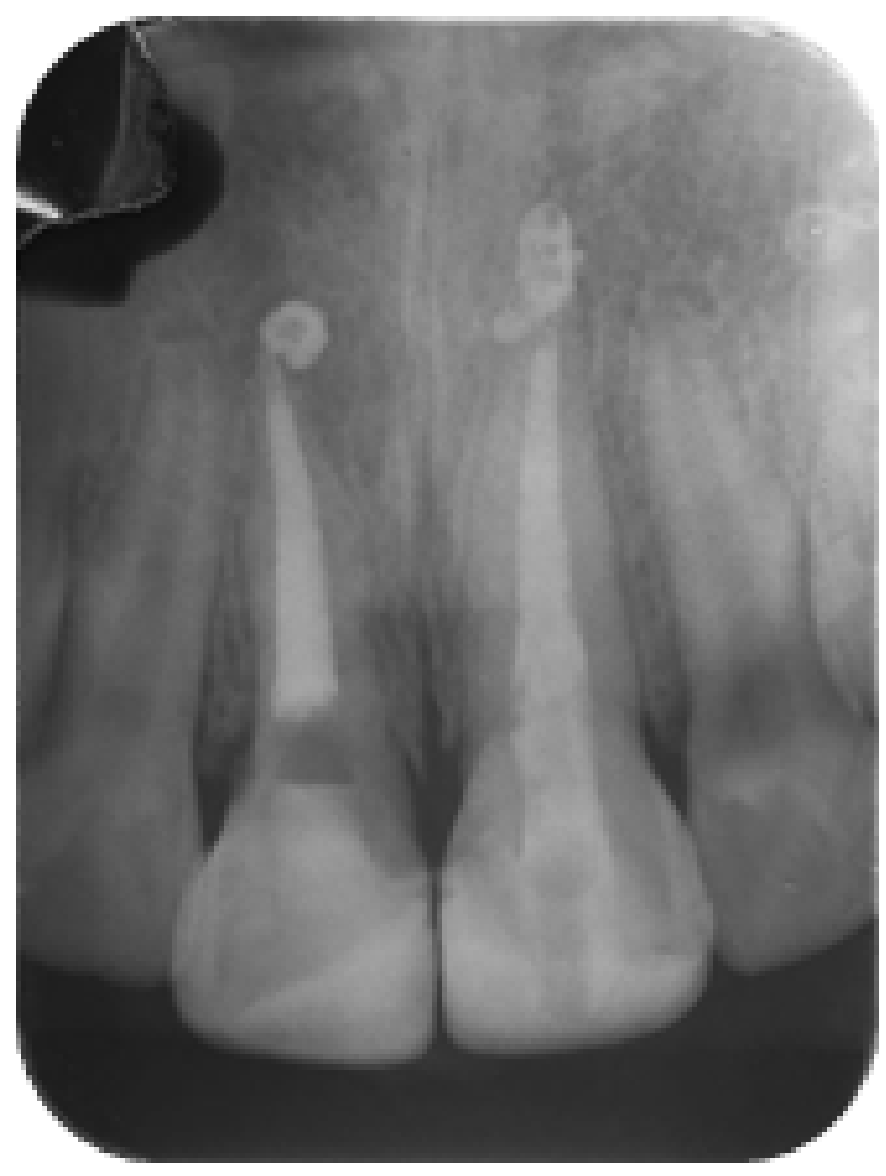

Figure 6. Radiographic aspect of endodontic treatment 1-year after trauma.

second place of demand for dental care (dental caries is the first one) [5].

Enamel-dentin-pulp-fracture treatment should be performed within 3 hours to achieve a success rate of 72-100\% [7]. In this case report, the endodontic treatment 
was performed 8 weeks after trauma, which may be an explanation for external root resorption. In addition, the involved teeth had complete root formation, and the literature indicates that teeth with open apex have a higher success rate [7].

In the case of luxation injuries, the tooth must be repositioned digitally into its original location [8]. In general, if there is no hard tissue fracture, a semi-rigid splint is indicated for 2-3 weeks [7], without occlusal interferences; otherwise, a rigid splint is indicated for 2 months. Some authors recommend a flexible splint for 4 weeks, specifically in cases of lateral luxation $[9,10]$.

Several splint materials are used, among them nylon wire, metallic wire and orthodontic brackets with passive arcs [1]. One can also use buccal arches or bars [11]. For better periodontal healing and less risk of ankyloses or external root resorption, a flexible splint is used. In this case report, a semi-rigid splint with orthodontic wire was used. Although it has been used for the recommended time (e.g., 4 weeks), the splint's material may have contributed to external root resorption.

Finally, fractured anterior teeth with unfavourable aesthetics may negatively affect self-esteem and interpersonal relationships, especially the upper central incisors, which are the teeth most affected by trauma and those most visible in the smile [12-14]. It is important that these dental elements be reconstructed, as they avoid changes in speech, chewing and psychological problems, thus providing healthier development for the child [15].

\section{CONCLUSION}

It was concluded that the proposed treatment for dental trauma reported here was satisfactory. As a sequela of trauma, external root resorption was observed, which remained stable after 1-year follow-up.

\section{Collaborators}

ALCS OMENA, clinical care, writing the manuscript, final approval of the version to be published. IA FERREIRA, clinical care, writing the manuscript, final approval of the version to be published. CL RAMAGEM and KMS MOREIRA, critical revision of the content, final approval of the version to be published. I FLORIANO and JC IMPARATO, clinical care, writing the manuscript, final approval of the version to be published.

\section{REFERENCES}

1. Panzarini SR, Pedrini D, Poi WR, Sonoda CK, Brandini DA, Monteiro de Castro JC. Dental trauma involving root fracture and periodontal ligament injury: a 10-year retrospective study. Braz Oral Res. 2008;22:229-234. http://dx.doi.org/10.1590/ S1806-83242008000300007

2. Lim L, Sirichai P. Bone fractures: assessment and management. Aust Dent J. 2016;61(1):74-81 http://dx.doi.org/10.1111/adj. 12399

3. Silveira JLGC, Bona AJ, Arruda JAB. Traumatismos Dentários em Escolares de 12 anos do Município de Blumenau, SC, Brasil. Pesqui Bras Odontopediatria Clin Integr. 2010;10(1):23-26. http://dx.doi.org/10.4034/1519.0501.2010.0101.0004

4. Hill CM, Burford K, Martin A, Thomas DW. A one year review of maxillofacial sports injuries treated at an accident and emergency department. $\mathrm{Br} J$ Oral Maxillofac Surg. 1998;36(1):44-47. http://dx.doi.org/10.1016/s0266-4356(98)90 747-1

5. Andreasen JO. Classificação, Etiologia e Epidemiologia. In: Andreasen JO, Andreasen FM. Texto e atlas colorido de traumatismo dental. Porto Alegre: Artmed; 2001. p.155-83.

6. Ramos-Jorge ML, Peres MA, Traebert J, Ghisi CZ, Paiva SM, Pordeus IA, Marques LS. Incidence of dental trauma among adolescents: A prospective cohort study. Dent Traumatol. 2008; 24:159-163. http://dx.doi.org/10.1111/J.1600-9657.2007. 00533.x

7. Dale RA. Dentoalveolar trauma. Emerg Med Clin North Am. 2000;18(3):521-539. http://dx.doi.org/10.1016/s0733-8627(05) 70141-3

8. Dewhurst SN, Mason C, Roberts CJ. Emergency treatment of orodental injuries: a review. Br J Oral Maxillo fac Surg, 1998;36(3):165-175. http://dx.doi.org/https://doi.org/10.10 16/S0266-4356(98)90491-0Get rights and content

9. Wanderley MT, Verrastro AP. Reabilitação e prótese em Odontopediatria. In: Guedes-Pinto AC, Bönecker M, Rodrigues CRMD. Fundamentos de Odontologia - Odontopediatria. São Paulo: Santos; 2009. p. 329-54.

10. Wanderley MT, Guedes CC. Traumatismos de dentes permanentes. In: Fernandes KPS, Puertas KV, Wanderley MT, Guedes CC, Bussadori SK. Traumatismo Dentoalveolar: Passo a Passo, permanentes e decíduos. São Paulo: Santos; 2009. p. 190-213.

11. Von AT, Filippi A, Buser D. Spliting of traumatized teeth with a new device: TTS (Titanium Trauma Splint). Dent Traumatol, 2001;17(4):180-184. http://dx.doi.org/10.1034/j.1600-9657. 2001.170408.x

12. Cavalcanti AL, Bezerra PKM, Alencar CRB, Moura C. Traumatic anterior dental injuries in 7-to 12-years-old Brazilian children. Dent Traumatol 2009;25(2):198-202. http://dx.doi. org/10.1111/j.1600-9657.2008.00746.x

13. Mota LQ, Targino AGR, Lima MGGC, Farias JFG, Silva ALA, Farias FFG. Estudo do Traumatismo Dentário em Escolares do Município de João Pessoa, PB, Brasil. Pesqui Bras Odontopediatria Clin Integr. 2011;11(2):217-222. http://dx.doi. org/10.4034/PBOCI.2011.112.11 
14. Bendo CB, Paiva SM, Varni JW, Vale MP. Oral healthrelated quality of life and traumatic dental injuries in Brazilian adolescents. Community Dent Oral Epidemiol. 2014;42(3):216-223. http://dx.doi.org/10.1111/cdoe.120 78

15. Lunardelli AN, Lunardelli SE, Pereira KCR, Xavier SC, Martins LGT, Traebert E, et al. Dental trauma and oral health-related quality of life in schoolchildren from public schools of a southern Brazilian city. RGO, Rev Gaúch Odontol. 2018;66(2):00-00. http://dx.doi.org/10.1590/1981- 863720180002000073300

Received on: 25/9/2018

Final version resubmitted on: 31/3/2019

Approved on: 4/4/2019 